\title{
Repellent Effects of Volatile Extracts from Herb Plants against Larvae of Pieris rapae crucivora Boisduval
}

\author{
Hiromi Ikeura (Corresponding author) \\ School of Agriculture, Meiji University \\ 1-1-1, Higashimita, Tama-ku, Kawasaki, Kanagawa, 214-8571, Japan \\ Tel: 81-44-934-7167Ｅ-mail: hikeura@meiji.ac.jp \\ Fumiyuki Kobayashi \\ Faculty of Applied Life Science, Nippon Veterinary and Life Science University \\ 2-27-5, Sakai, Musashino, Tokyo, 180-8602, Japan \\ Tel: 81-422-51-6121 E-mail: fkoba@nvlu.ac.jp \\ Yasuyoshi Hayata \\ School of Agriculture, Meiji University \\ 1-1-1, Higashimita, Tama-ku, Kawasaki, Kanagawa, 214-8571, Japan \\ Tel: 81-44-934-7812 E-mail: yhayata@meiji.ac.jp
}

Received: November 14, 2011

Accepted: December 6, 2011 Online Published: April 1, 2012

doi:10.5539/jas.v4n5p145

URL: http://dx.doi.org/10.5539/jas.v4n5p145

\begin{abstract}
Environmental pollution and intensive use of toxic chemicals, as well as resistance to pesticides, has forced scientists to find new ways of controlling pests. Numerous substances that repel insects and inhibit eating and egg-laying have been discovered in a variety of plants. The cabbage white butterfly, Pieris rapae crucivora Boisduval, is a serious pest to Brassicaca species such as cabbage, cauliflower and broccoli, and its larvae damage the host plant leaves when feeding. In this study, to develop a botanical insecticide against $P$. rapae larvae, we assessed the effect of 7 kinds of herb (rosemary, spearmint, eucalyptus, sage, chili pepper, chives and tansy) extracts as feeding repellents against $P$. rapae larvae. Feeding repellent tests were conducted by placing two cabbage leaf disks on filter paper treated with herb extract or diethyl ether in a box; then a larva was placed between the disks and its preference was observed. The repellent rate of rosemary, spearmint, eucalyptus, sage, chili pepper, chives and tansy was $75 \%, 72 \%, 64 \%, 59 \%, 40 \%, 40 \%$ and $36 \%$, respectively. These results clarified that of the tested herbs, rosemary and spearmint volatile extracts have a notable feeding repellent effect against $P$. rapae larvae.
\end{abstract}

Keywords: Pieris rapae, Larvae, Feeding repellent

\section{Introduction}

There are growing concerns on the use of chemical pesticides and fertilizers due to environmental pollution, adverse effects on human health, disruption of natural biological control and evolution of pesticide-resistant pest populations. As consumer interest in the safety of food and agricultural products has risen in recent years, producers are increasingly focused on pesticide-free and organic farming that take human health and the environment into account. In Japan, about 600 agricultural pesticides have been included in the Positive List since its introduction in 2006. This list details the maximum limits of chemical residues permissible in food products. Without the use of chemicals, however, farmers risk disease and insect damage to crops (Perry et al., 1998; Isman, 2006). Botanical insecticides are an environmentally friendly alternative to hazardous chemicals as they are plant-derived insecticides which occur either naturally or are extracts of such plants (Gupta et al., 2005) 
Many plant species are known to possess insecticidal properties, and the compounds from these plants have a number of useful activities such as toxicity, repellency, feeding and oviposition deterrence and insect growth regulation (Sharma and Gupta, 2009). In mixed vegetation, odors released by some plants can mask the effect of odors released by other plants (Cromartie, 1975), thereby disorientating insects such that they spend less time on plants suitable for egg-laying and feeding (Lamb, 1989). The cabbage white butterfly, Pieris rapae crucivora Boisduval, is a serious pest of Brassicaceae plants such as cabbage, cauliflower and broccoli (Ikeura et al., 2010), and its larvae damage the host plant leaves when feeding (Verschaffelt, 1911).

Gao et al. (2004) showed that deoxypodophyllotoxin, indentified in Juniperus Sabina L., has insecticidal activity against $P$. rapae larvae. In addition, Zhong et al. (2006) showed that rhodojaponin-III isolated from Rhododendron molle G. Don flowers is an antifeedant, stomach poison, contact toxicant and growth inhibitor against $P$. rapae. However, the compounds indentified in their study were non-volatile. Only a few reports have been published on the feeding repellent effect of volatile extracts against $P$. rapae larvae. In this study, we investigated the feeding repellent effect of 7 kinds of herb extracts to develop a botanical insecticide against $P$. rapae larvae.

\section{Materials and Methods}

This study was conducted at the laboratory and field of Meiji University from September 20th to December 20th 2007.

\subsection{Plants}

The following 7 plants, well known by agriculturists and horticulturists, and common in the literature, were selected as the basis for herbal extracts: rosemary (Rosmarinus officinalis L.), spearmint (Mentha spicata L.), eucalyptus (Eucalyptus globules L.), chives (Allium schoenoprasum L.), sage (Salvia officinale L.), tansy (Tanacetum rulgre L.) and chili pepper (Capsicum annuum L.).

\subsection{Insects}

Gravid female adults of P. rapae crucivora Boisduval were collected from cabbage patches in Kawasaki city. They were released in a cage $(1.6 \mathrm{~m} \times 1.6 \mathrm{~m} \times 1.8 \mathrm{~m})$ made from white shading net in a greenhouse of Meiji University, fed an approximately $10 \%$ sucrose solution and were free to oviposit on potted cabbages. When eggs were laid, the cabbages were placed under a natural condition in the greenhouse until hatching. The hatched larvae, which were fed cabbage in a plastic case $(10 \mathrm{~cm} \times 20 \mathrm{~cm} \times 7 \mathrm{~cm})$, were reared at $25^{\circ} \mathrm{C}$ under a $16 \mathrm{~L}: 8 \mathrm{D}$ regime until being at the fourth instar.

\subsection{Herb Extraction}

Ten grams of fresh leaves were homogenized and mixed with $40 \mathrm{ml}$ of diethyl ether at $4{ }^{\circ} \mathrm{C}$ for $4 \mathrm{~h}$ with a stirrer. Next, the sample was centrifuged at $12000 \mathrm{rpm}$ at $4{ }^{\circ} \mathrm{C}$ for $20 \mathrm{~min}$ and filtered, and the filtrate was used as the herb extract.

\subsection{Feeding Repellent Assay}

A feeding repellent assay was conducted on two cabbage leaf disks $(3 \mathrm{~cm} \times 3 \mathrm{~cm})$ on filter paper $(5 \mathrm{~cm} \times 5 \mathrm{~cm})$ treated with herb extract or diethyl ether in a box with dimensions of $20 \mathrm{~cm} \times 15 \mathrm{~cm} \times 8 \mathrm{~cm}$. A larva was placed between the disks, and the filter paper chosen by the larva was noted. Thirty larvae were used for each treatment. The repellent rate is expressed as follows: number of larvae choosing treated paper / (number of larvae choosing treated paper + number of larvae choosing control paper) $\times 100$.

\section{Results}

The repellent effect of each extract is shown in Fig. 2. Only rosemary $\left(75 \%\right.$; chi-test, $\left.\chi^{2}=14.75, p<0.001\right)$ and spearmint $\left(72 \% ; \chi^{2}=11.36, p<0.001\right)$ extracts had a significant feeding repellent effect against the larvae.

\section{Discussion}

Plants have wide action spectra, whereas a particular plant can affect insects though different mechanisms of action. In this study, rosemary and spearmint affected P. rapae larvae by inhibiting their feeding, suggesting the presence of feeding repellent compounds in the volatile extracts.

To date, there have been many studies on repellency and the insecticidal effects of herbs against pests (Dover, 1985; Jbilou, et al., 2006; Sharma and Gupta, 2009). Rosemary is known to have a repellent effect on various pests, and Hori (1998) and Sampson et al. (2005) reported that rosemary oil repelled the green peach aphid, Myzus persica and Lipaphis pseudobrassicae. Waliwitiya et al. (2009) assessed the essential oil of rosemary against larval stages of Aedes aegypti and found that the larvicidal activity of 5 terpenoids, pulegone, thymol, 
eugenol, trans-anethole, and citronellal exhibited high larvicidal activity against A. aegypti. Dover (1985) reported that the alcohol extract of rosemary has a repellent effect on $P$. brassicae. Moreover, mint oil is known to repel various pests and insects (Sampson, et al., 2005; Abbaszadeh, et al., 2009). However, there is no data on the antifeeding effects of rosemary on $P$. rapae larvae; nevertheless rosemary and spearmint are known to repel various pests.

P. brassicae belongs to the same family as $P$. rapae and avoids feeding on leaves treated with hyssop, rosemary, sage, thyme, white clover and eucalyptus (Dover, 1985; Sharma and Dupta, 2009). On the other hand, $P$. rapae larvae avoid feeding on the wild mustard, Erysimum cheiranthoides (Sachdev-Gupta et al., 1993). Thus, $P$. spp. reject various plants, these repellents are soluble. The findings of the present study suggest that compounds from rosemary may be volatile due to extract high volatile organic solvent. Furthermore, it seems desirable to use rosemary for companion plants.

In the future, we need to identify the feeding repellent compounds in rosemary. In conclusion, volatile extracts of rosemary and spearmint have a strong feeding repellent effect on $P$. rapae larvae.

\section{References}

Abbaszadeh B.,Valadabadi S. A., Farahani A. \& Darvishi H. H. (2009). Studying of essential oil variations in leaves Mentha speacies. African Journal of Plant Science, 3, $217-221$. http://dx.doi.org/10.1111/j.1570-7458.1985.tb03560.x

Dover J.W. (1985). The responses of some Lepidoptera to labiate herb and white extracts. Entomologia Experimentalis et Applicata, 39, 177-182.

Gao R., Gao C., Tian X., Yu X., Di X., Xiao H. \& Zhang X. (2004). Insecticidal activity of deoxypodophyllotoxin, isolated from Juniperus sabina L., and related lignans against larvae of Pieris rapae L. Pest Management Science, 60, 1131-1136. http://dx.doi.org/10.1002/ps.922

Gupta S., Sharma A.K. \& Sirohi A. (2005). Neem: A botanical pesticides. Indian Farmers Digest, 32, 35-36.

Hori M. (1998). Repellency of rosemary oil against Myzus persicae in a labolatory and in a screenhouse. Journal of Chemical Ecology, 24, 1425-1432. http://dx.doi.org/10.1023/A:1020947414051

Ikeura H., Kobayashi F. \& Hayata Y. (2010). How do Piersi rapae search for Brassicaceae host plants? Biochemical Systematics and Ecology, 38, 1199-1203. http://dx.doi.org/10.1016/j.bse.2010.12.007

Isman M. B.(2006). Botanical insecticides, detterrents, and repellents in modern agriculture and an increasingly regulated world. Annual Review of Entomology, 51, 45-66. http://dx.doi.org/10.1146/annurev.ento.51.110104.151146

Jbilou R., Ennabili A. \& Sayah F. (2006). Insecticidal activity of four medicinal plant extracts against Tribolium castaneum (Herbst) (Coleoptera: Tenebrionidae). African Journal of Biotechnology, 5, 936-940

Perry A. S., Yamamoto I. Ishaaya I. \& Perry R. Y. (1998). Insecticides in agriculture and environment: Retrospects and Prospects. Springer-Verlag, Berlin.

Sachdev-Gupta K., Radke C. D., Renwick J. A. A. \& Dimock M. B. (1993). Cardenolides from Erysimum cheiranthoides: feeding deterrents to Pieris rapae larvae. Journalof Chemical Ecology, 19, 1355-1369. http://dx.doi.org/10.1007/BF00984881

Sampson B. J., Tabanca N., Kirimer N., Demirci B., Baser K. H. C., Khan I. A., Spiers J. M. \& Wedge D. E. (2005). Insecticidal activity of 23 essential oils and their major compounds against adult Lipaphis pseudobrassicae (Davis) (Aphididae: Homoptera). Pest Management Science, 61, 1122-1128. http://dx.doi.org/10.1002/ps.1100

Sharma A. \& Gupta R. (2009). Biological activity of some plant extracts against Pieris brassicae (Linn.). Journal of Biopesticide, 2, 26-31.

Verschaffelt Ed. (1911). The cause determing the selection of food in some herbivorous insect. Proceedings Academy Science of Amsterdum, 1, 536-542.

Waliwitiya R., Kennedy C. J. \& Lowenberger C. A. (2009). Larvicidal and oviposition-alterinig activity of monoterpenoids, trans-anethole and rosemary oil to the yellow fever mosquito Aedes aegypti (Diptera: Culicidae). Pest Management Science, 65, 241-248. http://dx.doi.org/10.1002/ps.1675

Zhong G., Liu J., Weng Q., Hu M. \& Luo J. (2006). Laboratory and field evaluations of rhodojaponin-III against the imported cabbage worm Pieris rapae (L.) (Lepidoptera: Pierodae). Pest Management Science, 62, $976-981$. http://dx.doi.org/10.1002/ps. 1267 


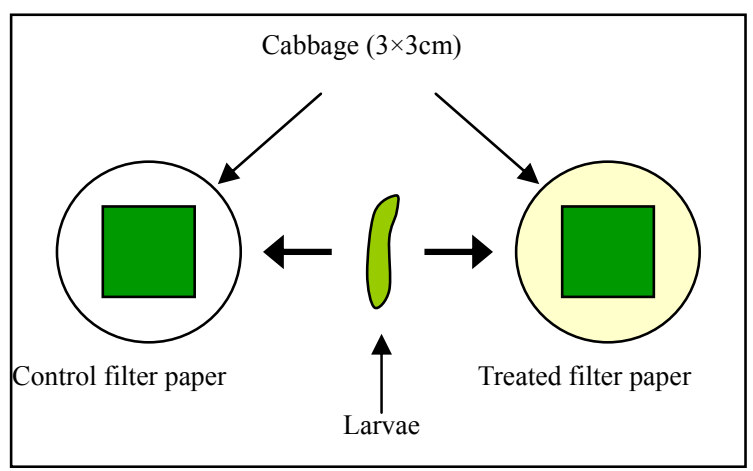

Figure 1. Preference of larvae to the cabbage leaf on treated filter paper $(5 \mathrm{~cm}$ in diameter)or the control

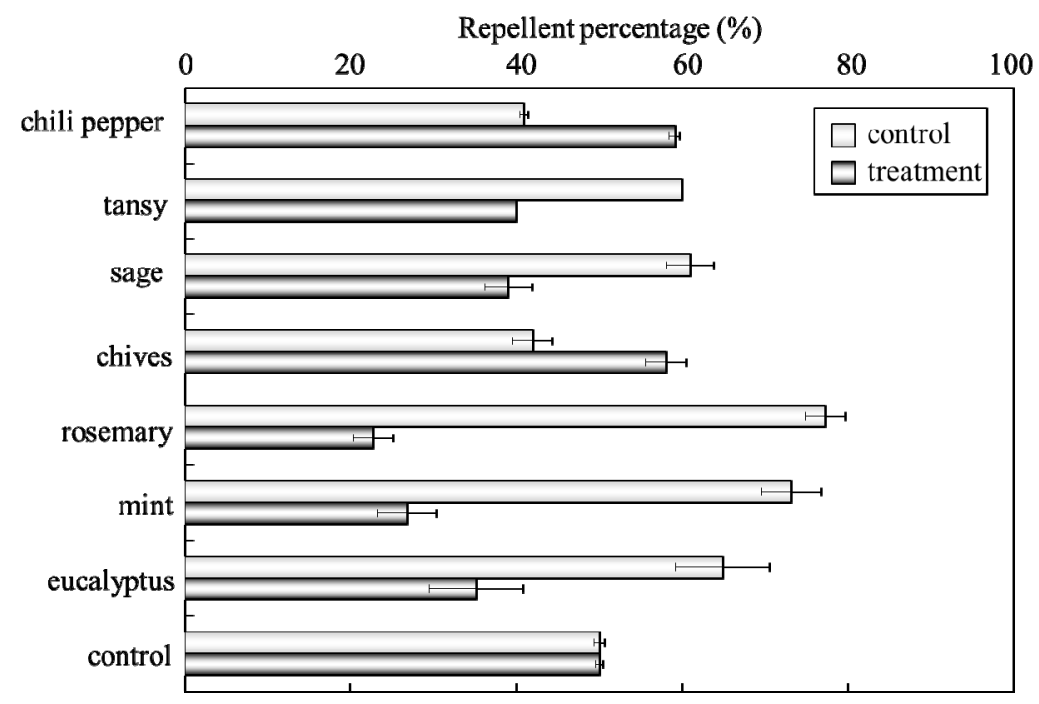

Figure 2. Repellent effect of 7 kinds of herb extracts against $P$. rapae larvae

Error bar indicates standard error $(n=10)$. The repellent rate was calculated as: (number of larvae that selected control filter paper) / (number of larvae that selected treated filter paper + number of larvae that selected control filter paper) $\times 100$. 